\title{
The Study of Insect Pests of Dalbergia sissoo Roxb. and Their Seasonal Incidence in Jharkhand, India
}

\author{
Arvind Kumar \\ Forest Entomology Division, Forest Research Institute, Dehradun, India \\ Email address: \\ arvind.ento@gmail.com \\ To cite this article: \\ Arvind Kumar. The Study of Insect Pests of Dalbergia sissoo Roxb. and Their Seasonal Incidence in Jharkhand, India. American Journal of \\ Agriculture and Forestry. Vol. 5, No. 5, 2017, pp. 137-144. doi: 10.11648/j.ajaf.20170505.11
}

Received: July 6, 2017; Accepted: July 24, 2017; Published: August 30, 2017

\begin{abstract}
Shisham Dalbergia sissoo Roxb. is the most popular and valuable timber species found throughout India-Pakistan sub-continent. The present study was undertaken in the province of Jharkhand to find out the insect pest fauna of D. sissoo their infestation and seasonal incidence. Total seventeen insect pests were recorded from the region out of which five insects belongs to Coleoptera viz. Apoderus sissu, Anomala dalbergiae, Anomala bengalensis, Myllocerus undecimpustulatus and Myllocerus discolour were observed. Similarly, five insect pests of order Lepidoptera viz. Agrotis ipsilon, Plecoptera reflexa, Ascotis infixaria, Dichomeris eridantis and Leucoptera sphenograpta were observed. Six insect pests belonging to order Hemiptera viz. Lawana conspersa, Ceroplastes rusci, Leptocentrus taurus, Myzus persicae, Icerya seychellarum, Drosicha dalbergiae and Odontotermes obesus. Among these, two insect pests Lawana conspersa and Icerya seychellarum were found first time on D. sissoo. Additionally, nature of damage, seasonal incidence and their infestation was also observed during the course of study.
\end{abstract}

Keywords: Dalbergia sissoo, Insect Pest, New Record, Insect Infestation, Jharkhand

\section{Introduction}

Dalbergia sissoo Roxb. is one of the valuable timber species occur naturally and plantation in Southeast Asia. It is a deciduous tree, also known as Shisham, Sisu or Sissoo mainly distributed in northern and central provinces of India. The tree is also known as Indian Rosewood. It is native to Indian subcontinent and southern Iran. It is the province tree of Punjab province of India and the provincial tree of Punjab province of Pakistan. It is primarily found growing along river banks at $900 \mathrm{~m}$ elevation, but can be raised naturally up to $1,300 \mathrm{~m}$. It can withstand average in the regions with annual rainfall up to $2,000 \mathrm{~mm}$. Soils range from pure sand and gravel to rich alluvium of river banks; shisham can grow in slightly saline soils. Bihar province is largest producer of D. sissoo and it is planted on roadside along canals and farmers field as bund plantation. Timber of this species is internationally known for its grain quality and strength. With its multiple products and qualities growth and productivity of D. sissoo forests are adversely affected by frequent outbreaks of insect pests. Several groups of insects belonging to orders, Coleoptera, Hymenoptera, Lepidoptera and Isoptera are the major pests that cause high economic loss to the nursery, natural and plantations. Among these most important pests are cutworms, termites and cockchafers besides some defoliators, sapsuckers and shoot borers as major pests. $D$. sissoo is attacked by about 207 insect species [1] and 22 phytophagous insect were reported from Madhya Pradesh [2]. Some more scattered works have been done on insect pests of D. sissoo, but none of the study has been done for the province of Jharkhand. Hence, this study was undertaken to find out the insect pest fauna associated with D. sissoo, their infestation and seasonal incidence in the province of Jharkhand, India.

\section{Methods}

The study was done in the province of Jharkhand lies at latitude $22^{\circ} 00^{\prime}$ and $24^{\circ} 37^{\prime} \mathrm{N}$ to longitude $83^{\circ} 15^{\prime}$ and $87^{\circ} 01 \mathrm{E}$, mainly geographical area is defined as plateau of Chota Nagpur. This study was undertaken in total 19 districts of Jharkhand namely Bokaro, Chatra, Deoghar, Dhanbad, East Singhbhum, Garhwa, Giridih, Gumla, Hazaribag, Khunti, Koderma, Latehar, Lohardaga, Plamu, Ranchi, Ramgarh, 
Saraikela Kharsawa, Simdega and West Singbhum. These districts are true representative of whole Jharkhand Province. The province has been divided into 3 agro-climatic sub zones viz., Central and North eastern plateau sub zone, Western plateau sub zone and South eastern Plateau sub zone. The soil of Jharkhand province is formed by the break down of rocks and stones and the composition of soil are red soil, micacious soil, sandy soil, black soil, and majority of laterite soil. The average temperature of the province is $25^{\circ} \mathrm{C}$, but the lowest temperature may fall at $5^{\circ} \mathrm{C}$ in winter and in summer it may rise upto $40^{\circ} \mathrm{C}$. The annual rainfall in the state is between 1200 $\mathrm{mm}$ to $1800 \mathrm{~mm}$ with an average of $1400 \mathrm{~mm}$ and the main rainy months are June to September [3]. Regular survey of insect pests of natural forest and plantations of $D$. sissoo was done at monthly interval. The random observation of insect pests associated with root, trunk, bark, shoot and leaf were done. The nature of damage done by the insect pest was also recorded in the field and in the laboratory while rearing. The larval stages of unidentified insect pests for $D$. sissoo were brought to the laboratory and reared for adult emergence and preserved for further identification and record. Insect pests were identified with the published literature and then confirmed from Zoological Survey of India (ZSI), Kolkata and Indian Agricultural Research Institute (IARI), New Delhi. Seasonal incidence of insect pests was also recorded on the basis of presence and their infestation in the field. The regular data recorded for three years were pulled and seasonal incidence was plotted for each insect pests. All the numeric data collected was processed for ANOVA through the statistics analysis software SPSS version 21.

\section{Results and Discussion}

The insect pests of D. sissoo and their nature of damage described insect wise (Table 1) revealed that total seventeen insect pests were recorded from the region out of which five insect pests were belongs to Coleoptera viz. Apoderus sissu, Anomala dalbergiae, Anomala bengalensis, Myllocerus undecimpustulatus and Myllocerus discolour were observed. Similarly, five insect pests of order Lepidoptera viz. Agrotis ipsilon, Plecoptera reflexa, Ascotis infixaria, Dichomeris eridantis and Leucoptera sphenograpta were observed. Six insect pests belonging to order Hemiptera viz. Lawana conspersa, Ceroplastes rusci, Leptocentrus taurus, Myzus persicae, Icerya seychellarum, Drosicha dalbergiae and one Odontotermes obesus was of order Isoptera. Among these Anomala bengalensis, Lawana conspersa and Icerya seychellarum was found to be first time as a new pest of $D$. sissoo in the world (Figure 1). The insect wise details, their nature of damage, seasonal incidence and their infestation is presented as follows:
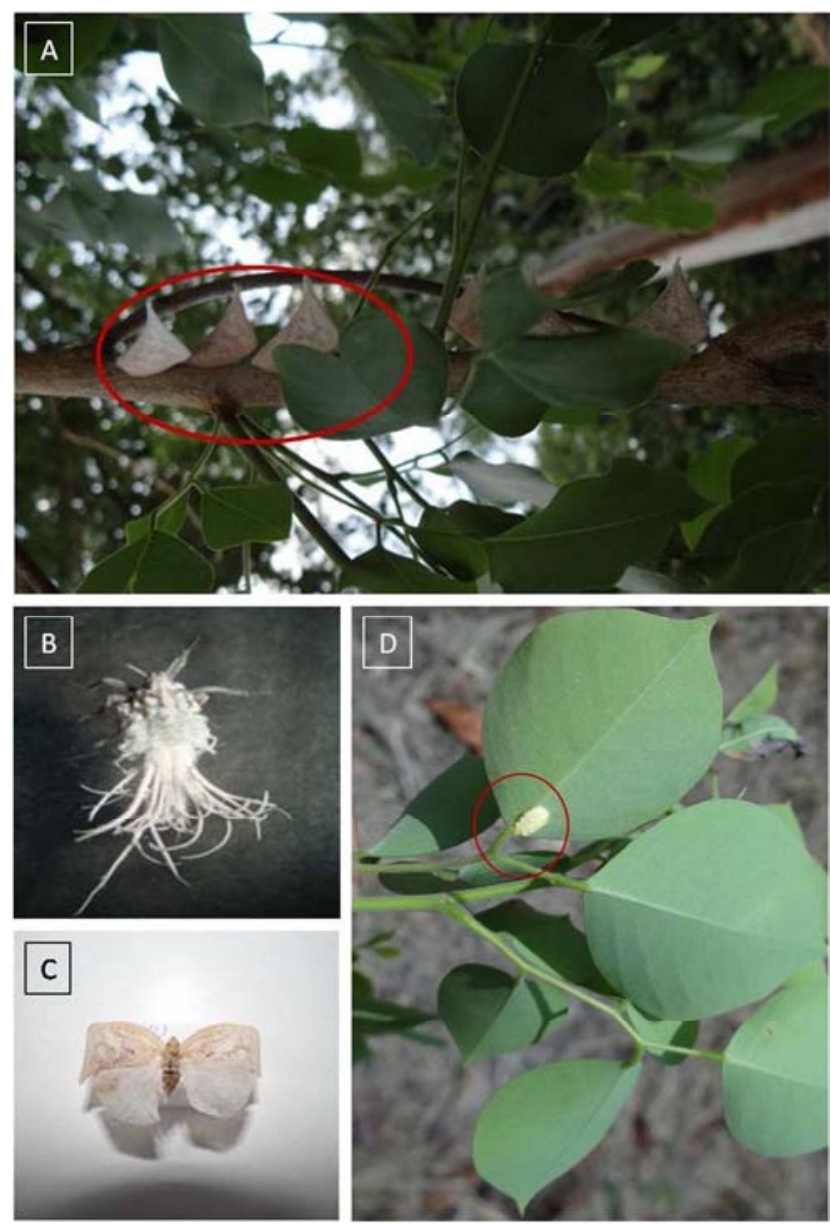

Figure 1. Newly reported insect pest of D. sissoo (A- L. conspersa adult feeding on D. sissoo; B-Nymph of L. conspersa; C-Aduly of L. conspersa; DIcerya seychellarum feeding on D. sissoo).

Table 1. Insect pest their status and nature of damage of insect pest infesting to the D. sissoo.

\begin{tabular}{|c|c|c|c|c|c|}
\hline Sl. & Name & Family & Common name & Infestation & Status \\
\hline \multicolumn{6}{|c|}{ Coleoptera } \\
\hline 1 & Apoderus sissu Marshall & Curculionidae & Leaf rolling & Leaf & Major \\
\hline 2 & Anomala dalbergiae Arrow & Scarabaeidae & Leaf beetle & Root/Leaf & Miner \\
\hline 4 & Myllocerus undecimpustulatus Foust & Curculionidae & Leaf Weevil & Leaf & Miner \\
\hline 5 & Myllocerus discolour (Boheman) & Curculionidae & Leaf Weevil & Leaf & Major \\
\hline \multicolumn{6}{|c|}{ Lepidoptera } \\
\hline 7 & Plecoptera reflexa Gunee & Noctuidae & Twig defoliator & Leaf & Major \\
\hline 8 & Ascotis infixaria Walk & Geometridae & Leaf caterpillar & Leaf & Major \\
\hline 9 & Dichomeris eridantisMeyr & Gelechidae & Leaf folder & Leaf & Major \\
\hline 10 & Leucoptera sphenograptaMeyr & Lyometidae & Leaf miner & Leaf & Miner \\
\hline \multicolumn{6}{|c|}{ Hemiptera } \\
\hline 11 & Lawana conspersa (Walk)* & Flatidae & Flatid bug & Shoot & Miner \\
\hline
\end{tabular}




\begin{tabular}{|c|c|c|c|c|c|}
\hline Sl. & Name & Family & Common name & Infestation & Status \\
\hline 12 & Ceroplastesrusci Linn & Coccidae & Wax scale & Shoot, leaf & Miner \\
\hline 13 & Leptocentrus taurus Febr & Membracidae & Cow bug & Shoot & Major \\
\hline 14 & Myzus persicae Sulzer & Aphididae & Aphid & Shoot, leaf & Miner \\
\hline 15 & Icerya seychellarum Westw* & Margarodidae & Mealy bug & Shoot, leaf & Miner \\
\hline 16 & Drosicha dalbergiae Stebb & Margarodidae & Mealy bug & Shoot, leaf & Miner \\
\hline \multicolumn{6}{|c|}{ Isoptera } \\
\hline 17 & Odontotermes obesus (Rambur) & Termitidae & Termite & Bark & Miner \\
\hline
\end{tabular}

\section{Apoderus sissu Marshall (Coleoptera: Curculeonidae)}

Both the adult and larval stages were found to cause damage to new flush either by rolling them off or by cutting through the mid rib and defoliation. Beetle was brightly colored yellowish red or testaceous with dark suffusion having three black spots on the Elytra. Female was larger than male. The activity of this insect was found from March to October, but they were found abundantly in March- April (Table 2). The infestation of Apoderus sissu was observed from all the districts and the maximum plant (29.83\%) infestation was recorded in Gumla district, while lowest in Deoghar (5.00\%) (Table 3). It has also been reported by [4] that leaf rolling weevil Apoderus sissuas one of the most serious defoliators of Dalbergia sissoo was subsequently it has been recorded by [5] from India.

\section{Anomala dalbergiae Arrow (Coleroptera: Scarabaeidae)}

It's both larvae and adult beetle were found to causes damage to the plant. Newly hatched larva feed on roots and rootlets of the seedlings and young plants. Mature larva was about 40-50 mm long, large, curved whitish with large brown head. Adult wasfound from May-October, (Table 2) appear in swarms after heavy monsoon rain shower and defoliate young plantation. The infestation of Anomaladalbergiae was observed from all the districts. The maximum plant infestation $(10.17 \%)$ was recorded in Koderma district, while lowest in Garhwa (1.33\%) (Table 3). This pest was also reported by [4] and [1] as a leaf defoliator of $D$. sissoo from India. Subsequently, M. dalbergia was also recorded as injurious insect pest of $D$. sissoo was supported by the results of [6] and [7].

Table 2. Seasonal activity of insect pest infesting to the D. sissoo.

\begin{tabular}{|c|c|c|c|c|c|c|c|c|c|c|c|c|c|}
\hline SI & Species/ Months & Jan & Feb. & Mar. & Apr. & May & Jun. & Jul. & Aug. & Sep. & Oct. & Nov. & Dec. \\
\hline \multicolumn{14}{|c|}{ Coleoptera } \\
\hline 1 & Apoderus sissu Marshall & & & + & + & + & + & + & + & + & + & & \\
\hline 2 & Anomala dalbergiae Arrow & & & & & + & + & + & + & + & + & & \\
\hline 3 & Anomala bengalensis (Blanchard) & & & & & & + & + & + & + & + & & \\
\hline 4 & Myllocerus undecimpustulatus Foust & & & & & + & + & + & + & + & & & \\
\hline 5 & Myllocerus discolour (Boheman) & & & & & + & + & + & + & + & & & \\
\hline \multicolumn{14}{|c|}{ Lepidoptera } \\
\hline 7 & Plecoptera reflexa Gunee & & & & + & + & + & + & + & + & + & & \\
\hline 8 & Ascotis infixaria Walk & & & + & + & + & + & + & + & + & + & & \\
\hline 9 & Dichomeris eridantis $\mathrm{Meyr}$ & & + & + & + & + & + & + & + & + & + & & \\
\hline 10 & Leucoptera sphenograpta Meyr & & & + & + & + & + & + & + & + & + & + & \\
\hline \multicolumn{14}{|c|}{ Hemiptera } \\
\hline 11 & Lawana conspersa (Walk) & & & + & + & + & + & + & + & + & & & \\
\hline 12 & Ceroplastes rusci Linn & + & + & + & + & + & + & + & + & + & + & + & + \\
\hline 14 & Myzus persicae Sulzer & + & + & + & & & & & & & & + & + \\
\hline 15 & Icerya seychellarum Westw & + & + & + & + & & & & & & & & + \\
\hline 16 & Drosicha dalbergiae Stebb & + & + & + & + & & & & & & & & + \\
\hline \multicolumn{14}{|c|}{ Isoptera } \\
\hline 17 & Odontotermes obesus (Rambur) & & + & + & + & + & + & + & + & + & + & + & \\
\hline
\end{tabular}

\section{Anomala bengalensis (Blanchard) (Coleoptera:} Scarabaeidae)

Both grub and beetle stages were found injurious to the plant. The swarming of this insect was occured in the month of May to June after first rainfall. The infestation of this insect was observed from all the districts except Dhanbad, East Singbhum, Giridih, and Saraikela Kharsawa. The maximum plant infestation (15.55\%) was observed in Plamu, while, in Dhanbad, East Singbhum and Saraikela Kharsawa no infestation was recorded (Table 2). This was first time observed in this study and none of the workers has reported this insect pest on D. sissoo earlier.

\section{Myllocerus undecimpustulatus Foust (Coleoptera: Curculionidae)}

Weevil was bright grayish or grayish pink in colour, 5-6 $\mathrm{mm}$ in length. The spots and black marking was observed on elytra of this weevil. Only adult stage was found to be injurious to the plant. Adult weevil nibble the leaves form the edges or even near the midrib and make irregular margin and defoliate the plant. The infestation period of this insect was found during May to September (Table 2). The infestation of Myllocerus undecimpustulatus, was observed only from six districts viz. Gumla, Hazaribag, Khunti, Latehar, Ranchi and Ramgarh. The maximum plant infestation (18.92\%) was 
observed in Ramgarh district, while, lowest in infestation $(3.83 \%)$ was in Khunti and in other districts no infestation was recorded (Table 3 ). This species was first identified by [8] in the Fauna of British India series and [9] have identified as Myllocerus undecimpustulatus Faust, a most serious pest specie of weevils species native to southern India in India and Pakistan.

Myllocerus discolour (Boheman) (Coleoptera: Curculionidae)

Adult weevil of this species was of black in colorwith pale brown markings on elytra. Body length was about 6.0 $\mathrm{mm}$. This species was found to cause damage to tender shoots and inflorescence. The activity period of this weevil was during May to September (Table 2). The infestation of
Myllocerus discolour was observed only from eight districts viz. Chatara, Gumla, Hazaribag, Khunti, Latehar, Lohardaga, Ranchi and Ramgarh. The maximum plant infestation was (16.25\%) was observed in Chatra district, while lowest in infestation (5.25\%) was in Khunti, but no infestation was recorded in other districts (Table 3). Myllocerus discolor was recorded in this study nibbling the plant leaf and infest to the $D$. sissoo this finding was supported by the [10] in which they has reported $M$. discolor from June to September. It was argued [8] that nymphs and adults of $M$. discolor caused 2 to $45 \%$ infestation and damage to foliage and twigs of young plants of $D$. sissoo during February to November in India.

Table 3. District wise extant of insect pest infestation on D. sissoo in Jharkhand, India.

\begin{tabular}{|c|c|c|c|c|c|c|c|c|c|}
\hline S. $\mathbf{L}$ & $\begin{array}{l}\text { Name of the districts } \\
\text { Insect name }\end{array}$ & $\begin{array}{l}\text { Apoderus } \\
\text { sissu }\end{array}$ & $\begin{array}{l}\text { Anomala } \\
\text { dalbergiae }\end{array}$ & $\begin{array}{l}\text { Anomala } \\
\text { bengalensis }\end{array}$ & $\begin{array}{l}\text { Myllocerus } \\
\text { undecimpustulatus }\end{array}$ & $\begin{array}{l}\text { Myllocerus } \\
\text { discolour }\end{array}$ & $\begin{array}{l}\text { Agrotis } \\
\text { ipsilon }\end{array}$ & $\begin{array}{l}\text { Plecoptera } \\
\text { reflexa }\end{array}$ & $\begin{array}{l}\text { Ascotis } \\
\text { infixaria }\end{array}$ \\
\hline 1 & Bokaro & 12.00 & 3.50 & 5.33 & 0.00 & 0.00 & 0.00 & 56.52 & 53.40 \\
\hline 2 & Chatra & 12.50 & 8.33 & 9.33 & 0.00 & 16.25 & 0.00 & 60.10 & 41.83 \\
\hline 4 & Dhanbad & 10.17 & 2.33 & 0.00 & 0.00 & 0.00 & 0.00 & 57.60 & 36.40 \\
\hline 5 & East Singhbhum & 8.17 & 7.33 & 0.00 & 0.00 & 0.00 & 6.02 & 50.43 & 48.47 \\
\hline 6 & West Singbhum & 9.83 & 3.00 & 3.58 & 0.00 & 0.00 & 0.00 & 65.20 & 54.42 \\
\hline 8 & Giridih & 9.17 & 4.83 & 0.00 & 0.00 & 0.00 & 0.00 & 58.08 & 36.82 \\
\hline 9 & Gumla & 29.83 & 1.67 & 7.87 & 11.33 & 14.05 & 0.00 & 74.52 & 50.50 \\
\hline 10 & Hazaribag & 22.83 & 2.50 & 5.35 & 9.57 & 10.17 & 0.00 & 67.12 & 49.17 \\
\hline 11 & Khunti & 17.83 & 3.67 & 8.92 & 3.83 & 5.25 & 4.33 & 48.30 & 46.43 \\
\hline 12 & Koderma & 18.33 & 10.17 & 7.12 & 0.00 & 0.00 & 0.00 & 50.37 & 57.50 \\
\hline 13 & Latehar & 19.33 & 2.83 & 7.52 & 5.62 & 10.02 & 0.00 & 72.52 & 37.13 \\
\hline 14 & Lohardaga & 21.67 & 2.33 & 9.93 & 0.00 & 15.83 & 0.00 & 61.27 & 28.10 \\
\hline 15 & Plamu & 9.67 & 9.67 & 15.55 & 0.00 & 0.00 & 0.00 & 53.27 & 56.68 \\
\hline 17 & Ramgarh & 10.83 & 2.67 & 5.17 & 18.92 & 12.48 & 0.00 & 78.40 & 42.62 \\
\hline 18 & SaraikelaKharsawa & 6.00 & 4.83 & 0.00 & 0.00 & 0.00 & 0.00 & 45.60 & 46.40 \\
\hline 19 & Simdega & 15.67 & 5.00 & 4.75 & 0.00 & 0.00 & 0.00 & 70.40 & 47.62 \\
\hline \multicolumn{2}{|c|}{$\mathrm{SEM} \pm$} & 2.53 & 1.23 & 1.09 & 0.64 & 1.09 & 0.29 & 5.38 & 3.67 \\
\hline \multicolumn{2}{|c|}{$\mathrm{CD}$ at $5 \%$} & 7.11 & 3.47 & 3.06 & 1.79 & 3.07 & 0.82 & 15.12 & 10.33 \\
\hline
\end{tabular}

Table 3. Continue.

\begin{tabular}{|c|c|c|c|c|c|c|c|c|c|c|}
\hline S. $\mathbf{L}$ & $\begin{array}{l}\text { Name of the districts } \\
\text { Insect name }\end{array}$ & $\begin{array}{l}\text { Dichomeris } \\
\text { eridantis }\end{array}$ & $\begin{array}{l}\text { Leucoptera } \\
\text { sphenograpta }\end{array}$ & $\begin{array}{l}\text { Lawana } \\
\text { conspersa }\end{array}$ & $\begin{array}{l}\text { Ceroplastes } \\
\text { r usci }\end{array}$ & $\begin{array}{l}\text { Leptocentr } \\
\text { us taurus }\end{array}$ & $\begin{array}{l}\text { Myzus } \\
\text { persicae }\end{array}$ & $\begin{array}{l}\text { Icerya } \\
\text { seychellarum }\end{array}$ & $\begin{array}{l}\text { Drosicha } \\
\text { dalbergiae }\end{array}$ & $\begin{array}{l}\text { Odontoterme } \\
\text { s obesus }\end{array}$ \\
\hline 1 & Bokaro & 43.80 & 55.87 & 0.00 & 0.00 & 75.25 & 54.50 & 0.00 & 0.00 & 91.83 \\
\hline 2 & Chatra & 76.83 & 82.17 & 0.00 & 0.00 & 86.12 & 44.27 & 0.00 & 0.00 & 92.13 \\
\hline 3 & Deoghar & 83.55 & 74.82 & 0.00 & 0.00 & 79.70 & 47.47 & 0.00 & 0.00 & 93.80 \\
\hline 4 & Dhanbad & 54.73 & 57.20 & 0.00 & 0.00 & 68.02 & 38.13 & 0.00 & 0.00 & 87.08 \\
\hline 5 & East Singhbhum & 58.80 & 67.53 & 0.00 & 0.00 & 79.58 & 62.88 & 0.00 & 0.00 & 93.50 \\
\hline 6 & West Singbhum & 47.55 & 52.70 & 0.00 & 0.00 & 87.68 & 53.53 & 0.00 & 11.28 & 88.17 \\
\hline 8 & Giridih & 74.63 & 73.45 & 0.00 & 0.00 & 72.55 & 25.48 & 10.63 & 9.17 & 92.50 \\
\hline 9 & Gumla & 57.88 & 62.55 & 9.27 & 12.83 & 76.78 & 44.63 & 5.80 & 6.87 & 94.00 \\
\hline 10 & Hazaribag & 43.38 & 45.33 & 0.00 & 0.00 & 80.18 & 37.50 & 8.80 & 10.32 & 90.23 \\
\hline 11 & Khunti & 52.80 & 58.12 & 16.85 & 17.50 & 71.77 & 38.60 & 6.50 & 0.00 & 87.68 \\
\hline 12 & Koderma & 86.15 & 85.87 & 0.00 & 0.00 & 84.42 & 33.55 & 0.00 & 0.00 & 90.37 \\
\hline 13 & Latehar & 42.28 & 46.02 & 0.00 & 18.15 & 87.22 & 36.32 & 0.00 & 10.73 & 93.92 \\
\hline 14 & Lohardaga & 52.50 & 55.17 & 3.50 & 0.00 & 68.27 & 39.47 & 0.00 & 8.70 & 88.70 \\
\hline 15 & Plamu & 68.78 & 65.60 & 0.00 & 0.00 & 64.65 & 28.55 & 0.00 & 5.80 & 91.10 \\
\hline 17 & Ramgarh & 65.93 & 65.48 & 14.43 & 0.00 & 72.62 & 37.40 & 0.00 & 6.50 & 91.23 \\
\hline 18 & SaraikelaKharsawa & 56.50 & 57.57 & 0.00 & 0.00 & 78.50 & 41.87 & 0.00 & 0.00 & 90.53 \\
\hline 19 & Simdega & 49.37 & 51.22 & 12.97 & 0.00 & 84.67 & 38.08 & 0.00 & 0.00 & 95.40 \\
\hline \multicolumn{2}{|c|}{$\mathrm{SEM} \pm$} & 3.16 & 3.06 & 0.73 & 0.44 & 2.84 & 2.03 & 0.48 & 0.64 & 3.73 \\
\hline \multicolumn{2}{|c|}{$\mathrm{CD}$ at $5 \%$} & 8.89 & 8.59 & 2.06 & 1.25 & 7.98 & 5.71 & 1.35 & 1.81 & 10.49 \\
\hline
\end{tabular}




\section{Agrotis ipsilon Rott. (Lepidoptera: Noctuidae)}

The larva of this insect was found only in nursery only just below the surface of the soil feeding on the seedlings. Adult of this insect was moth dark colored; medium sized having dark, blackish colour with grayish patches on the dorsal side. Wings expanse 40 to $50 \mathrm{~mm}$. Larva stout bodied having short hairs, cylindrical and earth coloured speckled with white or black. The adult of this pest emerge was emerged out in the month of October and remains active up-to April (Table 2). The infestation of this pest was observed only from nursery plants in three districts viz. East Singbum, Khunti and Ranchi. The maximum nursery plant infestation $(7.00 \%)$ was in Ranchi followed by East Singbum (6.03\%) and Khunti (4.33\%). Other sixteen districts were not infested with this insect (Table 3). It has also reported by [1] this insect pest infesting to D. sissoo in India. But none of the worker has reported this insect pest from Jharkhand province of India.

Plecoptera reflexa Guenee (Lepidoptera: Noctuidae)

P. reflexawas found to be a major pest and its larval stages was found to cause a major defoliation to the plant in both the nursery and old plantation. Moth was nocturnal in habit. Wing expanse $30-35 \mathrm{~mm}$. Forewings were grayish with oblique irregular bands, underside was grayish white. Adult moths hide in undergrowth vegetation during day time and active in night hours. Caterpillar was semilooper, smooth, cylindrical, green in colour having eight bands on the dorsal side. Mature larva was pinkish. The maximum damage of this defoliator attack was observed during May and June, but the insect was found active up to October (Table 2). Due to severe infestation of larval causes defoliation of the trees. Infestation of Plecoptera reflexa was recorded from all the districts and the maximum plant infestation $(78.40 \%)$ was observed in Ramgarh, while lowest in infestation $(45.60 \%)$ was in Saraikela Kharsawa (Table 3). Similarly, [11] reported defoliator caterpillar Plecoptera reflexaas an important defoliator of D. sissoo in Pakistan. In India this pest was reported in the province Madhya Pradesh [12,13] (Kalia et al., 2000 and Bhan, et al., 2005); in Uttarakhand population dynamics of P. reflexa and Dichomeris eridantis $[14,15,16]$.

\section{Ascotis infixaria Walker (Lepidoptera: Geomatridae)}

The only larva of this insect was found to be injurious to the plant. Caterpillar was light pale in $25-30 \mathrm{~mm}$ long, ochreous black in colour. Larval period was 3 to 5 weeks, completed during June- September, depends upon the favorable condition. Pupation takes place in the soil on in the plant debris. This infestation period of this pest was recorded from April- October (Table 2). The pest population was found highest during summer. Infestation of Ascotis infixaria was recorded from all the districts and the maximum plant infestation $(57.50 \%)$ was observed in Koderma, while lowest in infestation $(26.67 \%)$ was in Deoghar (Table 3). It was recorded [17] Ascotis imparata pest infesting to D. siaaooand studied its biology in Uttarakhand-India. Though, this pest was also reported on Moringa pterygospermaby [18] in Madhya Pradesh, India.

Dichomeris eridantis Meyrick (Lepidoptera: Gelechidae)
The larval stage of insect was found to be injurious to the plant and the caterpillar defoliates the tree, feeding within the leaf fold or rolled leaves. Moth was small wing expanse 16.0 $\mathrm{mm}$. Larva greenish yellow or dark grey with two faint submedian lines, slightly flattened. Head and Pronotum black. Mature larva $25 \mathrm{~mm}$ long. The activity of this insect was observed from February to October (Table 2). Infestation of Dechomeris eridentisa major insect pest of D. sissoo was recorded from all the districts. The maximum plant infestation $(86.15 \%)$ was observed in Koderma, while lowest in infestation (42.28\%) was in Latehar (Table 3). It was recorded by [14] and [15] has also reported that Dichomeris eridantis infesting to D. sissoo in Uttarakhand- India and subsequently, population dynamics of Dichomeris eridantiswas studied by [16]. Seasonal incidence of leaf binder, D. eridantiswas studied by [19] and moderate to maximum occurrence of this pest was recorded from February to October.

Leucoptera sphenograpta Meyrick (Lepidoptera: Lyonetidae)

The larval stage of this pestwas found to be causes damage to the plant with mining to the leaves, results discolouration spots and curling of leaves and premature leaf shedding. Moth was small 4.0-4.5 mm long, shining, white in colour. Fore wings were narrow, tipped with ocherous and a black apical spot with fuscous bars. Larva was light green with brown head and tapers posterioly. This pest was found active during March to November (Table 2). Infestation of Leucopterasphenograptaa major insect pest of $\mathrm{D}$. sissoowas recorded from all the districts and maximum plant infestation $(85.87 \%)$ was observed in Koderma, while lowest in infestation (45.33\%) was in Hazaribag (Table 2). It was observed by [20] that Leucoptera sphenograpta as a leaf-miner on Dalbergia sissoo in nurseries and plantations from Punjab, Haryana, Uttar Pradesh, Bihar and West Bengal, and Madhya Pradesh. It has reported [21] that an outbreak of L. sphenograpta on D. sissoo in Madhya Pradesh, India, in November to January, but none of the study was reported from Jharkhand.

\section{Lawana conspersa (Walker)(Hemiptera: Flatidae)}

This was the first observation of this pest infesting to $D$. sissoo in India. Both nymph and adult of this pest were found to be injurious to the plant. The nymph of this insect feed gregariously and adult scattered but some time in group on tender shoot, leaves and fruit of the plant. The body of the adult insect was creamish white with black spots on the fore wings and orange strips on basal portion of forewings. While hind wings were pure off-white. Newly hatched nymphs were white colored having waxy covering on the body and long waxy tail. The activity period was recorded from Match to August (Table 2). The infestation of this insect was observed only from five districts viz. Gumla, Khunti, Lohardaga, Ranchi and Ramgarh. The maximum plant infestation $(16.85 \%)$ was observed in Khunti district, followed by Ranchi (15.67\%), Ramgarh (14.43\%), Gumla (9.27\%) and lowest $3.50 \%$ in Khunti district (Table 3). Lowana conspersa insect pest was first time recorded from $D$. sissoo in this study, though this insect has been reported on Flemingia sp. 
Butea monosperma, Cajanus cajan, Zizyphus mauritiana and Dalbergia assamica [22] and Fleminagia semialata [23]. Coccoa and Bauhina spp. damage is caused by nymph and adult by sucking sap from tender leaf, flower and fruits [24] in Malaysia, but this insect pest was never been reported as pest on D. sissoo in the world.

\section{Ceroplastes rusci (Linnaeus) (Hemiptera: Coccidae)}

This insect was about 3-4 mm, globular and coated with a layer of beige, pinkish and whitish wax. Adult female scale was found permanently attached with the branches or leaves. Both the crawler stage and adults feed upon the succulent parts of the plant. The scale was found on both the upper and lower surface of leaves. The effect of its infestation was resulted leaf yellowing, leaf fall and branch dieback (Table 2). The infestation of this insect was observed only in five districts viz. Garhwa, Gumla, Khunti, Latehar and Ranchi. The maximum plant infestation $(24.15 \%)$ was observed in Ranchi district, followed by Larehar (18.15\%), Khunti (17.50\%), Gumla (12.83\%) and lowest $12.50 \%$ in Garhawa district (Table 3). Similarly, this fig wax scale, C. rusci was first time reported by [25] Kumar, (2013) in India, which was considered as the serious scale insect pest of $D$. sissoo.

Leptocentrus taurus Febr. (Hemiptera: Membracidae)

The insect species was found everywhere in the province and found very common. Both the adults and nymphs were found to suck the sap from the tender parts particularly from the shoot during March to June. The adult female was observed to lay their eggs on the shootinserted in the bark. Newly emerged nymph was light green colored and mature insect in black with two small thorns on the head in addition to one long thorn in backward direction. Body was about 4-5 $\mathrm{mm}$ long and $2 \mathrm{~mm}$ wide (Table 2). Infestation of L. taurusa major insect pest of $D$. sissoo was recorded from all the districts. The maximum plant infestation (91.57\%) was observed in Garhawa, while lowest in infestation (64.65\%) was in Plamu (Table 3). This is the first report of this pest from $D$. sissoo, though it has been reported that pest feeding on Parthenium hysterophorusin Tamilnadu, India [26] and many more countries [27].

Myzus persicae Sulzer (Hemiptera: Aphididae)

This Myzus persicae aphid species was found upon the tender leaves and shoot and causes damage by sucking plant sap. They feed gregariously on tender parts including leaves and shoo of the plant. Body was delicate, small, $2 \mathrm{~mm}$ long and blackish or purple in colour. They secrete honey dew on which sooty mould develops and hampers the photosynthesis process. The infestation of this insect was observed during November to March (Table 2). Infestation of M. persicaea sap sucking insect pest of $D$. sissoo was recorded from all the districts. The maximum plant infestation $(62.88 \%)$ was observed in East Singhbhum, while lowest infestation $(25.48 \%)$ was in Giridih district (Table 3). This insect was also reported by [28] and [29] on D. sissoo from India and [30] has reported in Pakistan.

Icerya seychellarum (Westwood) (Hemiptera: Margarodidae)

The body of the insect was observed very soft with yellow- white cottony hairs. Both the nymph and adults stages were observed equally injurious to the plant. Newly emerged nymph feed on the succulent part and leaves of the plant. This insect was secreted honey dew and subsequently, developed sooty mould upon it. Female insect was wingless, orange yellow, covered with white wax, while male was winged. Body of female insect was distinctly segmented. This insect pest was found active during December to April (Table 2). The infestation of Icerya seychellarum was observed only from five districts viz. Giridih, Garhwa, Gumla, Hazaribag, Khunti and Ranchi. The maximum plant infestation (10.63\%) was observed in Giridih district, followed by Hazaribag (8.80\%), Ranchi (8.70\%), Khunti $(6.0 \%)$, and lowest $(5.8 \%)$ in Gumla district (Table 3$)$. This insect was first time recorded in this study in Jharkhand, India.

\section{Drosicha dalbergiae Green (Hemiptera: Margarodidae)}

Both nymph and adult stages of this insect was found feeding to the sap of new foliage and shoots. This insect was secreted honey dew on which sooty mould developed, resulted blocking of stomata and disruption in photosynthesis of the pant. Females adult wingless, orange yellow, covered with white waxy powder. The appendages were black. Body is distinctly segmented. This insect was found active during December to April (Table 2). The infestation of Drosicha dalbergiae was observed only in ten districts viz. West Singhbhum, Garhawa, Giridih, Gumla, Hazaribag, Latehar, Lohardaga, Plamu, Ranchi and Ramgarh. The maximum plant infestation (11.28\%) was observed in West Singhbhum, while lowest (5.8\%) in Garhwa district (Table 3). This insect was also reported by [1] and [31] on D. sissoo in India and by [30] in Pakistan.

\section{Odontotermes obesus Rambur (Isoptera: Termitidae)}

This insect was found infested to live plant in the nursery to old plantation. The insect was found colonized in soil and feed on the plant root, dead bark and damaged wood of the plant. This insect was found to be the major insect pest throughout the Jharkhand and the major activity perios was observed from February to November. The maximum plant infestation (95.40\%) was observed in East Singhbhum, while lowest infestation (87.08\%) was observed in Dhanbad (Table $3)$. The infestation of termite was also noticed in the findings of [32] [33] (2005) and Singh and Pandey (2007) that a wide mortality of $D$. sissoo was caused by termites as common enemies of the trees. Subsequently [34] has also reported a termite Odontotermes redemanni attacking to D. sissoo and many species of Odontotermes infecting to D. sissoo has been reported [35, 36, 37, 38].

\section{Conclusion}

About 209 insect pests were already recorded from all over the India, while only seventeen insect pests were recorded from the Jharkhand Provence in this study. Among these two insect pests namely Lawana conspersa and Icerya seychellarum were recorded first time from $D$. sissoo in this study. This may be due variation in vegetation, soil profile, and 
climatic condition, additionally, seasonal incidence of the insect pests was also found different from the earlier records. Hence, it may be concluded the infestation of insect pest and their seasonal incidence may be depends on soil type and mainly climatic condition, which may shifted with the change of climatic condition. Therefore, assessment of insect pest of major forestry species should be done at a defined interval so that epidemic of any new insect pests may be avoided.

\section{References}

[1] Khan HR.: Insect pest of Dalbergia and their management. Indian Council of Forestry Research and Education, Dehradun, India. pp 141. (1995).

[2] Kalia S., Lal RR.: Insect pests of Dalbergia sissoo Roxb. at and around Jabalpur. Advances in Forestry Research in India. 20, 190-202. (1999).

[3] Anonymous: NIDM Jharkhand National Disaster Risk Reduction Portal. http://nidm.gov.in/PDF/DP/JHARKHAND.PDF. 38 pp (online). (2017).

[4] Beeson CFC.: Indian Forest Records, Entomology. P 16-18. (1938).

[5] Sharma B., Bhatia S: On the distribution, morphology and colour variations in Apoderus sissu Marshall, a defoliator of Dalbergia sissoo (Roxb.) in Jammu forests. Journal of Insect Science. 6 (2), 256-258. (1993).

[6] Sah SB., Ali MS.: Population dynamics of Oxyrachis tarandus Fab. on sapling of Dalbergia sissoo. Journal of Applied Biology. 15 (2), 47-50. (2005).

[7] Sah SB., Manual SK., Ali MS.: Evaluation of insecticides against Myllocerous discolor on shisham sapling in nursery. Environment and Ecology. 26 (1): 238-239. (2008).

[8] Marshall AKG.: The Fauna of British India, Coleoptera. 386. (1916).

[9] O 'Brien CW., Haseeb M., Thomas MC.: Myllocerus undecimpustulatus undatus Marshall (Coleoptera: Curculionidae), a Recently Discovered Pest Weevil from the Indian Subcontinent. Entomology Circular No. 412. Fla. Dept. of Agriculture \& Cons. Svs. Division of Plant Industry. (2006).

[10] Ramamurthy VV., Ghai SA.: study on the genus Myllocerus (Coleoptera: Curculionidae). Oriental Insects. 22, 377-500. (1988).

[11] Chaudhry MI.: Efficacy of botanical pesticides against Plecoptera reflexa Guen. (Noctudiae, Lepidoptera), shisham defoliator. Pakistan Journal of Forestry. 42: 4, 199-202. (1992).

[12] Kalia S., Malviya., RK., Pandey VP.: Achaea janata Linn. (Noctuidae: Lepidoptera) pest of Dalbergia sissoo - a new report. Indian Forester. 126 (8), 905. (2000).

[13] Bhan N., Kalia S., Ahmad M.: The consumption and utilization of Shisham leaves by the larvae of Plecoptera reflexa Guenee (Lepidoptera: Noctuidae). Indian Journal of Forestry. 28 (4), 377-380. (2005).

[14] Prasad L., Ansari IA., Chandra S.: A new predator of Plecoptera reflexa Guen. Uttar Pradesh Journal of Zoology. 21 (1), 95-96. (2001).
[15] Prasad L., Ansari IA., Chandra S., Prasad L., Chandra S.: Outbreak of shisham (Dalbergia sissoo) defoliator, Plecoptera reflexa (Guen.) (Lepidoptera: Noctuidae) in Doon Valley, India. Annals of Forestry, 7 (2), 297-298. (1999).

[16] Prasad L., Ansari IA., Chandra S.: Pest status, growth and development of Plecoptera reflexa (Lepidoptera: Noctuidae) and Dichomeris eridantis (Lepidoptera: Gelechiidae) on shisham, Delbergia sissoo. Uttar Pradesh Journal of Zoology. 22 (2), 175-178. (2002).

[17] Singh KP.: Effect of different host plants on the biology of polyphagus insect AscotisimparataWalk (Lepidoptera: Geometridae). Indian Forester. 136 (11), 1515-1519. (2010)

[18] Kulkarni N., Kalia S., Sambath S., Joshi KC.: First report of Ascotis selenariaimparata Walk. (Lepidoptera: Geometridae) as a pest of Moringa pterygosperma Gertn. Indian Forester. 122 (11), 1075-1076. (1996).

[19] Ali MS., Azam F., Chaturvedi OP.: Studies on seasonal occurrence, incidence and population fluctuation of shisham leaf binder, Dichomeris eridantis Mey. Indian Journal of Agroforestry. 9 (2), 121-124. (2007).

[20] Roychoudhury N.: Pest status of shisham leaf-miner, Leucoptera sphenograptaMeyrick. Advances in Forestry Research in India. 21: 222-226. (1999).

[21] Shaw SS., Badaya AK., Verma RS., Mandloi KC.: Tetrastichus sp. and Closterocerus sp. two new parasites of Leucoptera sphenograpta Meyrick. Indian Journal of Plant Protection. 18 (1), 137. (1990).

[22] Mohansundaram A., Sharma KK., Meena SC.: New record of Lawana consepersa (Walker). Indian Journal of Entomology. 75 (4), 399-401. (2012).

[23] Meena SC., Sharma KK., Mohansundaram A., Verma S., Monoburullah M.: Insect pest Complex of Flemingia semialata- A bushy host plant for lac cultivation. The Bioscan. 9 (4), 1375-1381. (2014).

[24] Ibrahim AG., Ibrahim DK.: Biology of Lawana conspersa Wal (Homoptera: Flatidae) a miner pest of Cocoa in Malaysia. Malaysian Applied Biology. 18, 93-98. (1989).

[25] Kumar A.: Fig wax scale, Ceroplastes rusci an emerging pest of Dalbergia sissoo and its parasitisation in India. Int. J. Curr. Sci. 8: E 106-114. (2013).

[26] Thangavelu K.: Report of Leptocentrus taurus fabricius (Membracidae: Homoptera) feeding on Partheniumhysterophorus Linn. Entomon. 5 (4), 357. (1980)

[27] McKamey S.: MOWD: Membracoidea of the World Database (version 1011, Nov 2010). In: Roskov Y., Abucay L., Orrell T., Nicolson D., Bailly N., Kirk P. M., Bourgoin T., DeWalt R. E., Decock W., De Wever A., Nieukerken E. van, Zarucchi J., Penev L., eds. (2017). Species 2000 \& ITIS Catalogue of Life, 30th June 2017. Digital resource at www.catalogueoflife.org/col. Species 2000: Naturalis, Leiden, the Netherlands. (2017).

[28] Behura BK.: Aphids of India. Survey of published information. Recent Adv. Zool. India, 1961: 25-78. (1963 b)

[29] Singh R., Singh G., Singh K., Sharma A.: Biodiversity of Aphids (Insecta: Homoptera: Aphididae) Infesting Legumes (Angiospermae: Fabales: Fabaceae) in India. International Journal of Research Studies in Zoology (IJRSZ) 2 (1), 30-44. (2016). 
[30] Duke JA.: Dalbergia sissoo Roxb. ex DC. Hand book of energy crops. published online https://www.hort.purdue.edu/newcrop/duke_energy/Dalbergia _sissoo.html. (1983).

[31] Manjhi C.: Insect pest association in Dalbergia sissoo, paddy based agrisilviculture system. Ph.D. Thesis Submitted to the Jawaharlal Nehru Krishi Vishwa Vidyalaya, Jabalpur. Pp 68. (2013).

[32] Sharma A., Kaushal P., Banyal R., Verma TD.: Role of insect pests in the mortality of Kikar and Shisham in Punjab. IndianForester. 131 (12), 1577-1582. (2005).

[33] Singh C., Pandey VP.: Natural resistance in Shisham clones against a defoliator Plecopterareflexa Guen. (Lepidoptera: Noctuidae) in foothills of Himachal Pradesh. I ndian Forester. 133 (9), 1270. (2007).
[34] Verma SC.: Termite pests of forestry and agriculture in Haryana, India. Indian Journal of Forestry, 12 (1), 1-6. (1989).

[35] Shakoor A., Akhtar MS., Awan S.: Feeding preferences of termites of Azad Kashmir. Pakistan Journal of Zoology. 23 (4), 355-359. (1991)

[36] Patel M., Sahu AK.: Control of termite attack on some high pulp yielding trees. Indian Forester. 121 (4), 295-299. (1995).

[37] Arshad J., Afzal M.: Incidence of termite attack on trees in University of the Punjab, Quaid-e-Azam Campus, Lahore, Pakistan. Pakistan Journal of Zoology. 2001; 33 (1), 80-82. (2001).

[38] Singh C., Pandey VP., Kalia S.: Natural resistance in Shisham against Odontotermes parvidens Holmgren (Isoptera: Termitidae) in foothills of Western Himalayas. Indian Journal of Forestry. 26 (1), 80-82. (2003). 